\title{
Cadmium and Lead Uptake by Ryegrass, Lettuce and White Mustard Plants on Different Soils
}

\author{
${ }^{1}$ É. LEHOCZKY, ${ }^{2}$ T. NÉMETH, ${ }^{1}$ Zs. KISS and ${ }^{3}$ T. SZALAI \\ ${ }^{1}$ University of Veszprém, Georgikon Faculty of Agriculture, Keszthely, ${ }^{2}$ Research \\ Institute for Soil Science and Agricultural Chemistry (RISSAC) of the Hungarian \\ Academy of Sciences, Budapest and ${ }^{3}$ Szent István University, Gödöllő (Hungary)
}

The soil-plant system is an open system subject to inputs, such as contaminants, fertilizers and pesticides, and outputs, such as the removal of metals by harvested plant material, leaching, erosion and volatilization. $\mathrm{Cd}$ and $\mathrm{Pb}$ potentially endanger the soil, air and water, thus plants and especially animals and humans. The highly labile behaviour of $\mathrm{Cd}$ in soil, especially those contaminated with relatively high concentrations of the metal, is an important factor in the accumulation of $\mathrm{Cd}$ from the point of view of human health (ALLOWAY, 1995). The FAO WHO limits accepted for heavy metal content from food to humans are 0.5 and $3.5 \mathrm{mg} \cdot$ person $^{-1} \cdot \mathrm{week}^{-1} \mathrm{Cd}$ and $\mathrm{Pb}$ (BERGMANN, 1992).

The atmospheric dry and wet sediments can also transport heavy metals to the environment. In Hungary the mean $\mathrm{Cd}$ and $\mathrm{Pb}$ values in the dry sediments are 0.056 and $0.322 \mathrm{mg} \cdot \mathrm{m}^{-2} \cdot$ year $^{-1}$, respectively (MÉSZÁROS et al., 1988).

In general $\mathrm{Pb}$ gets into the soil in a form unavailable to plants, and the organic matter has an outstanding role in $\mathrm{Pb}$ fixation and creating a complex bond with this element (ANDERSSON, 1977). Pb can reach man through the crop only in case the soil is strongly contaminated. If it penetrates through the membrane of the rootlets further movement is difficult and finally it remains in the root system (SZABÓ, 1992). In a pot experiment with ryegrass TAKÁCS et al. (2001) found that the accumulation of different heavy metals $(\mathrm{Cd}, \mathrm{Zn}, \mathrm{Ni})$ was higher in the roots than in the shoots.

Phytoremediation can be a method for the amelioration of contaminated soils. In order to apply this remediation process effectively we should know how and to what extent can different plant species accumulate heavy metals, such as $\mathrm{Cd}$ and $\mathrm{Pb}$. Plant species and varieties (cultivars) differ greatly in their ability to absorb, accumulate and tolerate heavy metals. DAVIS \& CALTONSMITH (1980) studied the $\mathrm{Cd}$ and $\mathrm{Pb}$ accumulation of different plants (Table 1).

Correspondence to: Dr. Éva LEHOCZKY, Veszprém University, Georgikon Faculty of Agriculture. H-8360 Keszthely, Deák F. út 16. Hungary. E-mail: lehoczky@georgikon.hu 
Table 1

Relative metal accumulations ( $\mathrm{Cd}$ and $\mathrm{Pb}$ in edible portions) DAVIS \& CALTON-SMITH (1980)

\begin{tabular}{|c|l|l|}
\hline Metal & \multicolumn{1}{|c|}{ High accumulations } & \multicolumn{1}{|c|}{ Low accumulations } \\
\hline $\mathrm{Cd}$ & Lettuce, cabbage, celery & Potato, maize, peas \\
$\mathrm{Pb}$ & Ryegrass, celery & Potato, maize \\
\hline
\end{tabular}

In addition, toxicity is influenced by a great number of soil and botanical characteristics. KÁDÁR (1995) suggested that the heavy metal uptake of plants depends on local (site) characteristics, like soil, farming patterns, climate, etc. The typical $\mathrm{pH}$ value of the given soil type has significant importance in the uptake of heavy metals (LEHOCZKY et al., 1996, 1998.)

The aim of the experiments was to obtain results of $\mathrm{Cd}$ and $\mathrm{Pb}$ uptake by different plant species in relation to the heavy metal content and different characteristics of soils.

\section{Materials and Methods}

The pot experiment was carried out in 2000 under greenhouse conditions with seven different soils originating from the measuring sites of the Hungarian Soil Conservation Information and Monitoring System (TIM). Soil samples varied in many physical and chemical characteristics, and in $\mathrm{Cd}$ and $\mathrm{Pb}$ content as well. From the seven experimental soils five samples (S1-S5) were collected from agricultural areas (arable sites) and two (S6-S7) from the so-called special sites. These two soils, representing spoil-earth, had extremely high $\mathrm{Cd}$ and $\mathrm{Pb}$ contents, manifoldly exceeding the limits permissible in Hungary.

For the greenhouse experiment soil samples were collected from the 0-20 $\mathrm{cm}$ surface layer. The experimental soils (according to the FAO Soil Classification) are: S1: Gleyic Luvisol; S2: Eutric Cambisol; S3: Histic Gleysol; S4 and S5: Mollic Fluvisol; S6 and S7: Eutric Fluvisol (spoil-earth). The main physical and chemical properties of the experimental soils are presented in Table 2.

The "total" amount of $\mathrm{Cd}$ and $\mathrm{Pb}$ in soil samples was measured after microwave digestion with cc. $\mathrm{HNO}_{3}+\mathrm{H}_{2} \mathrm{O}_{2}$. The so-called "available" $\mathrm{Cd}$ and $\mathrm{Pb}$ fraction of soils was determined by $0.1 M \mathrm{KCl}+0.05 M$ EDTA extraction (BARANYAI et al., 1987).

The experiment was carried out in four replicates. The pots, filled with $1 \mathrm{~kg}$ air-dry soil, were kept at constant soil moisture $(60 \%$ of maximum water capacity of the experimental soils) by daily watering, while pots were watered to weight once weekly. Before sowing the three test plants: $50-50-50 \mathrm{mg} \mathrm{N}$, $\mathrm{P}_{2} \mathrm{O}_{5}$ and $\mathrm{K}_{2} \mathrm{O}$ was applied to the experimental soils to maintain the same nutrient supply. CHAMINADE $(1960,1964)$ elaborated a method, which was 
Table 2

Physical and chemical properties of the soils used in the greenhouse experiment

\begin{tabular}{|c|c|c|c|c|c|c|c|}
\hline Soil property & S1 & $\mathrm{S} 2$ & S3 & S4 & S5 & S6 & S7 \\
\hline \multicolumn{8}{|l|}{$\mathrm{Cd}, \mathrm{mg} \mathrm{kg}^{-1}$ soil } \\
\hline Total $^{\mathrm{a}}$ & 1.61 & 1.82 & 1.63 & 1.91 & 1.94 & 4.93 & 16.80 \\
\hline Available $^{\mathrm{b}}$ & 0.11 & 0.19 & 0.11 & 0.30 & 0.24 & 2.04 & 6.24 \\
\hline \multicolumn{8}{|l|}{$\mathrm{Pb}, \mathrm{mg} \mathrm{kg}^{-1}$ soil } \\
\hline Total $^{\mathrm{a}}$ & 25.50 & 16.20 & 33.75 & 47.35 & 68.42 & 188.25 & 1232.35 \\
\hline Available $^{\mathrm{b}}$ & 6.40 & 7.52 & 4.90 & 8.60 & 9.27 & 71.67 & 386.35 \\
\hline $\mathrm{pH}\left(\mathrm{H}_{2} \mathrm{O}\right)$ & 7.39 & 7.89 & 7.53 & 7.24 & 7.20 & 7.91 & 7.36 \\
\hline $\mathrm{pH}(\mathrm{KCl})$ & 6.65 & 7.38 & 6.56 & 6.09 & 6.10 & 7.07 & 6.96 \\
\hline Hydrolytic acidity, & 2.63 & 1.37 & 2.95 & 5.89 & 6.06 & 1.67 & 3.17 \\
\hline $\begin{array}{l}\mathrm{y}_{1} \\
\text { CEC, } \\
\text { meq } 100 \mathrm{~g}^{-1} \text { soil }\end{array}$ & 19.80 & 49.30 & 30.84 & 46.26 & 40.78 & 39.04 & 39.89 \\
\hline $\mathrm{C} \%$ & 0.73 & 0.78 & 1.21 & 1.58 & 1.73 & 1.81 & 1.94 \\
\hline Clay \% $(<0.002)$ & 17.29 & 18.82 & 23.84 & 49.45 & 45.37 & 21.70 & 29.62 \\
\hline Silt \% $(0.02-0.002)$ & 36.93 & 23.38 & 26.95 & 29.17 & 40.08 & 18.05 & 21.04 \\
\hline
\end{tabular}

Remarks: ${ }^{\mathrm{a}}$ in cc. $\mathrm{HNO}_{3}+\mathrm{H}_{2} \mathrm{O}_{2},{ }^{\mathrm{b}}$ in $\mathrm{KCl}+$ EDTA

adapted in our experiment. Seeds of the three test plants - ryegrass (Lolium perenne L. cv. Georgikon), lettuce (Lactuca sativa L. cv. Balatonzöld) and white mustard (Sinapis alba L. cv. Sirola) - were sown in the pots. The abovesoil plant parts were cut after four weeks. Fresh and dry weights of plants were determined after harvest. The $\mathrm{Cd}$ and $\mathrm{Pb}$ contents of plant samples were measured after microwave digestion with cc. $\mathrm{HNO}_{3}+\mathrm{H}_{2} \mathrm{O}_{2}$ by using ICP-AES. Soil $\mathrm{pH}\left(\mathrm{pH}\left(\mathrm{H}_{2} \mathrm{O}\right), \mathrm{pH}(\mathrm{KCl})\right)$, hydrolytic acidity $\left(\mathrm{y}_{1}\right), \mathrm{CEC}$, clay, silt and organic carbon contents were determined. Mathematical statistical analysis of the experimental data was done by ANOVA using of Standard Package of the Statistical Software (SPSS).

\section{Results and Discussion}

The experimental soils can be characterized by different $\mathrm{Cd}$ and $\mathrm{Pb}$ contents (Table 2 ). The heavy metal content of the S6 soil is 2.5-3 times higher than that of the S1-S5 soils. The S7 soil, collected from spoil-earth, has extremely high $\mathrm{Cd}$ and $\mathrm{Pb}$ contents due to anthropogenic contamination. The $\mathrm{Cd}$ concentration of this soil is 4- and 9-10 times greater than that of S6 and S1-S5 soils. From the "total" Cd content $7-41 \%$ was in the so-called phytoavailable (soluble in $\mathrm{KCl}+\mathrm{EDTA}$ ) form. A close, linear regression was found between the "total" and $\mathrm{KCl}+\mathrm{EDTA}$ soluble Cd content of the soils: $\mathrm{y}=0.4041 \mathrm{x}+0.4483$, $r^{2}=0.9838, n=28$. 
There are significant differences among soils related to their $\mathrm{Pb}$ concentrations as well. A 1.5-2-fold difference occurred in $\mathrm{Pb}$ contents of soils S1-S5, while the difference between the S6 soil and S1-S5 soils was 3-12-fold, and that of the S7 soil and S1-S5 soils 6.5-77-fold. 14 to $46 \%$ of the "total" $\mathrm{Pb}$ content was found in $\mathrm{KCl}+\mathrm{EDTA}$ soluble form. A positive, linear regression was established between the "total" and $\mathrm{KCl}+\mathrm{EDTA}$ soluble $\mathrm{Pb}$ content of the soils: $\mathrm{y}=0.3159 \mathrm{x}+2.0685, \mathrm{r}^{2}=0.9958, \mathrm{n}=28$.

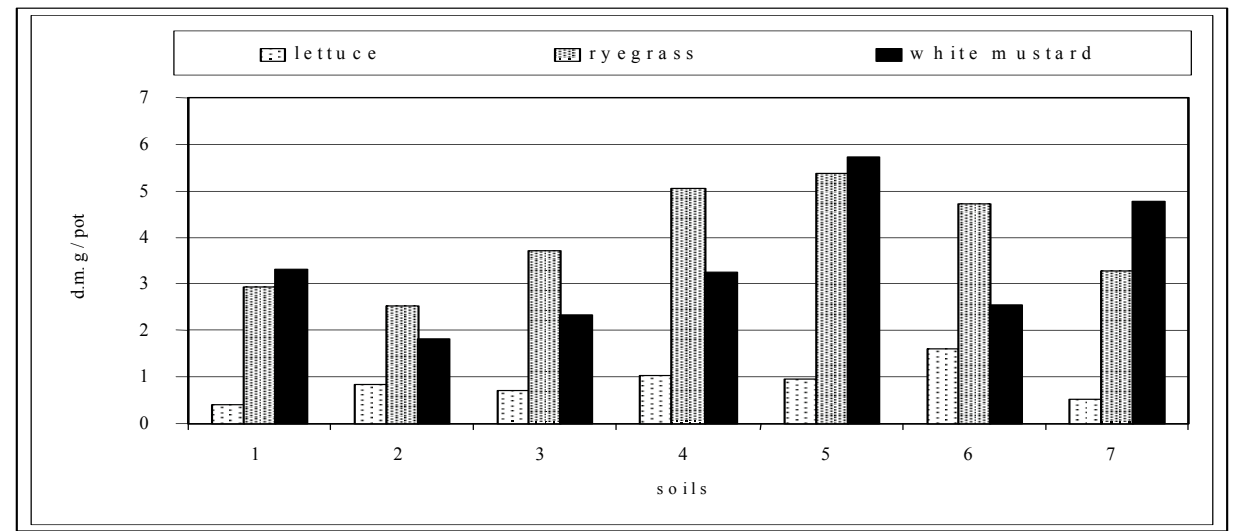

Figure 1

The biomass production of the test plants (ryegrass, lettuce and white mustard)

The biomass production of the three test plants is shown in Figure 1. No definite correlation was obtained between the biomass production of the 3 test plants and the heavy metal content of the soils at early growth stage. According to our results the heavy metal uptake by different plants can be compared in relation to the heavy metal content of the experimental soils.

\section{Cd uptake by plants}

The Cd concentration in the above-ground parts of the test plants varies in a wide range, from 0.15 to $11.06 \mathrm{mg} \cdot \mathrm{kg}^{-1}$, which represents a 73 -fold difference between the lowest and highest concentrations. This can be explained partly by species characteristics and partly by the different $\mathrm{Cd}$ content of the experimental soils.

A wider interval was found in the case of plants' Cd contents than for the "total" soil Cd contents, where a 10-fold difference was the greatest. Test plants differed significantly in $\mathrm{Cd}$ uptake. The lowest $\mathrm{Cd}$ content was obtained in ryegrass, however, it depended greatly on the soil. The $\mathrm{Cd}$ content ranged between 0.15 and $1.36 \mathrm{mg} \cdot \mathrm{kg}^{-1}$, giving a 9-fold difference. Much higher $\mathrm{Cd}$ concentrations $\left(0.91-7.20 \mathrm{mg} \cdot \mathrm{kg}^{-1}\right)$ were found in the shoots of white mustard 
The width of the concentration range is similar to that of ryegrass, the highest value being 7 times higher than the lowest.

The Cd concentration of lettuce was the highest in each experimental soil, varying between 1.4 and $11.1 \mathrm{mg} \cdot \mathrm{kg}^{-1}$, with an 8 -fold difference between the lowest and highest values.

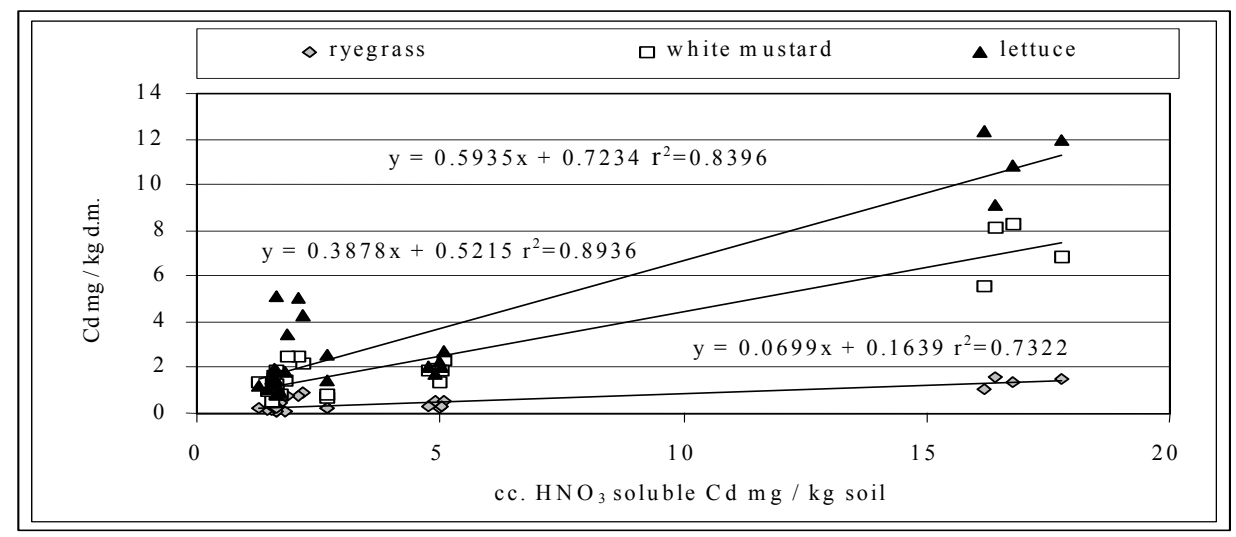

Figure 2

Correlation between the "total" Cd content of soil and Cd concentration of plants

Comparing the Cd content of the 3 test plants the order can be set up as follows: ryegrass $<$ white mustard $<$ lettuce. The difference between white mustard and ryegrass $\mathrm{Cd}$ concentrations was 3-6-fold, while that of lettuce and ryegrass was 5-10-fold. Comparing the Cd concentration of lettuce and mustard, a significantly lower (1.5-fold) difference was found (Figure 2).

The increase in the "total" and $\mathrm{KCl}+\mathrm{EDTA}$ soluble Cd content of the soil resulted the increased $\mathrm{Cd}$ contents of the test plants. A close positive, linear regression was found between the "total" Cd content of the soil and the Cd concentration of all 3 test plants (Figure 2). A positive linear regression was obtained between the $\mathrm{KCl}+\mathrm{EDTA}$ soluble $\mathrm{Cd}$ content of the experimental soils and the $\mathrm{Cd}$ concentration of the above-ground plant parts too: lettuce: $\mathrm{y}=1.4289 \mathrm{x}+$ $1.4591, \mathrm{r}^{2}=0.8065, \mathrm{n}=28$; white mustard: $\mathrm{y}=0.9326 \mathrm{x}+1.0036, \mathrm{r}^{2}=0.8565, \mathrm{n}$ $=28$; ryegrass: $\mathrm{y}=0.1674 \mathrm{x}+0.2517, \mathrm{r}^{2}=0.6961, \mathrm{n}=28$.

The Cd concentration in the plants was $8-231 \%$ of the total Cd content of the soils. Plant $\mathrm{Cd}$ accumulation was observed in lettuce and mustard in the S5 soil, which could not be explained solely by the Cd concentration of the soil. In our opinion different soil properties play an important role in this, e.g. soil $\mathrm{pH}$ and hydrolytic acidity $\left(\mathrm{y}_{1}\right)$ and silt $\%$ that were the highest in this soil (Table 2 ).

The "total" Cd uptake by plants showed significant differences in accordance with plants and soils, which originated from the specific uptake charac- 
teristics described above and partly from the biomass production. The Cd uptake by lettuce was the highest on the S7 soil. The Cd uptake of ryegrass and mustard was similar to that of lettuce on this strongly contaminated soil (S7), with values of 4.5 and $34.6 \mu \mathrm{g} \cdot$ pot $^{-1}$, respectively (Figure 4).

In this case too, the 3-3.5-fold increase in the Cd concentration of shoots (as compared to the S6 soil) was the main reason of the higher Cd uptake of plants. In the case of mustard the biomass was higher too, nearly 2 times more than in the S6 soil, however the biomass itself would not have caused such an increase (nearly 7-fold) in Cd uptake.

\section{Pb uptake by plants}

The $\mathrm{Pb}$ content of the soils has varied in a much wider range (16.2-1232 $\mathrm{mg} \cdot \mathrm{kg}^{-1}$ soil) that meant a 76 -fold difference between the lowest and highest values (Table 2).

The $\mathrm{Pb}$ concentration of above-ground plant parts ranged from 1 to 55 $\mathrm{mg} \cdot \mathrm{kg}^{-1}$ (Figure 3). The highest $\mathrm{Pb}$ content for all 3 test plants was observed on the strongly contaminated S7 soil.

The $\mathrm{Pb}$ concentration of plants - as compared to the "total" $\mathrm{Pb}$ content of soils - was $0.8-8 \%$, while in case of the $\mathrm{KCl}+\mathrm{EDTA}$ soluble $\mathrm{Pb}$ form it was $2.7-2 \%$. It was the $\mathrm{Pb}$ content of soil that determined the uptake. A close, positive regression was found between the total $\mathrm{Pb}$ content of the soils and the $\mathrm{Pb}$ concentration of plants (Figure 3). A positive linear regression was obtained between the $\mathrm{KCl}+\mathrm{EDTA}$ soluble $\mathrm{Pb}$ content of the experimental soils and the $\mathrm{Pb}$

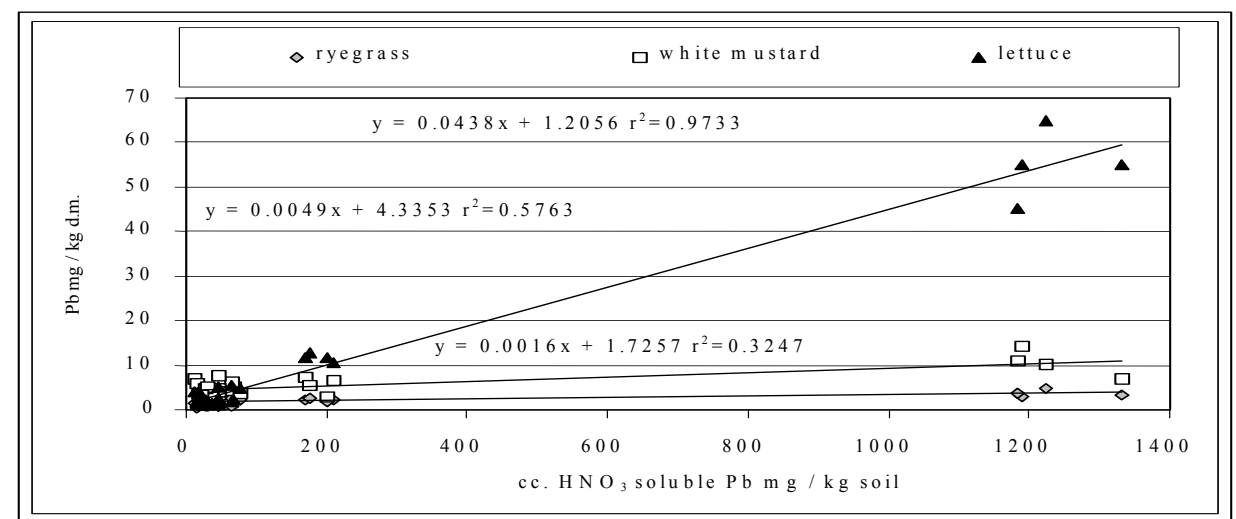

Figure 3

Correlation between the "total" $\mathrm{Pb}$ content of soil and $\mathrm{Pb}$ concentration of ryegrass, lettuce and white mustard test plants 


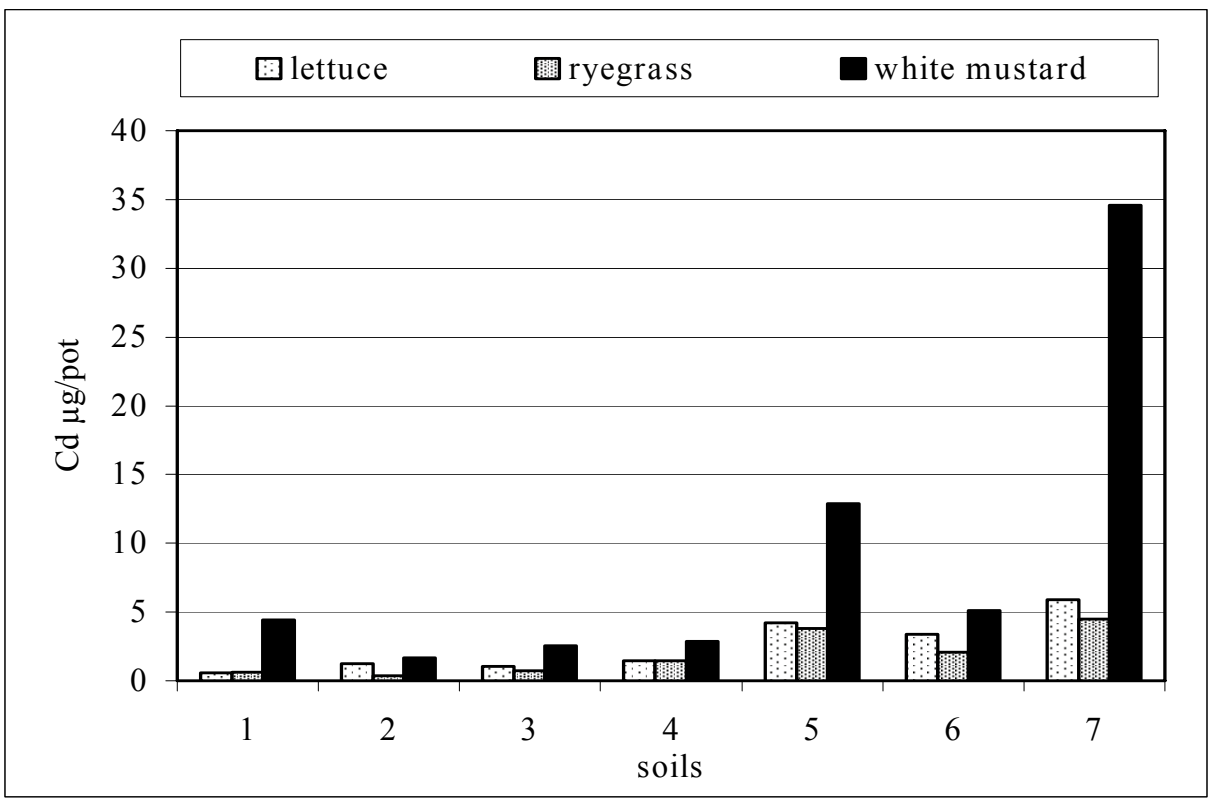

Figure 4

The Cd uptake by ryegrass, lettuce and white mustard test plants

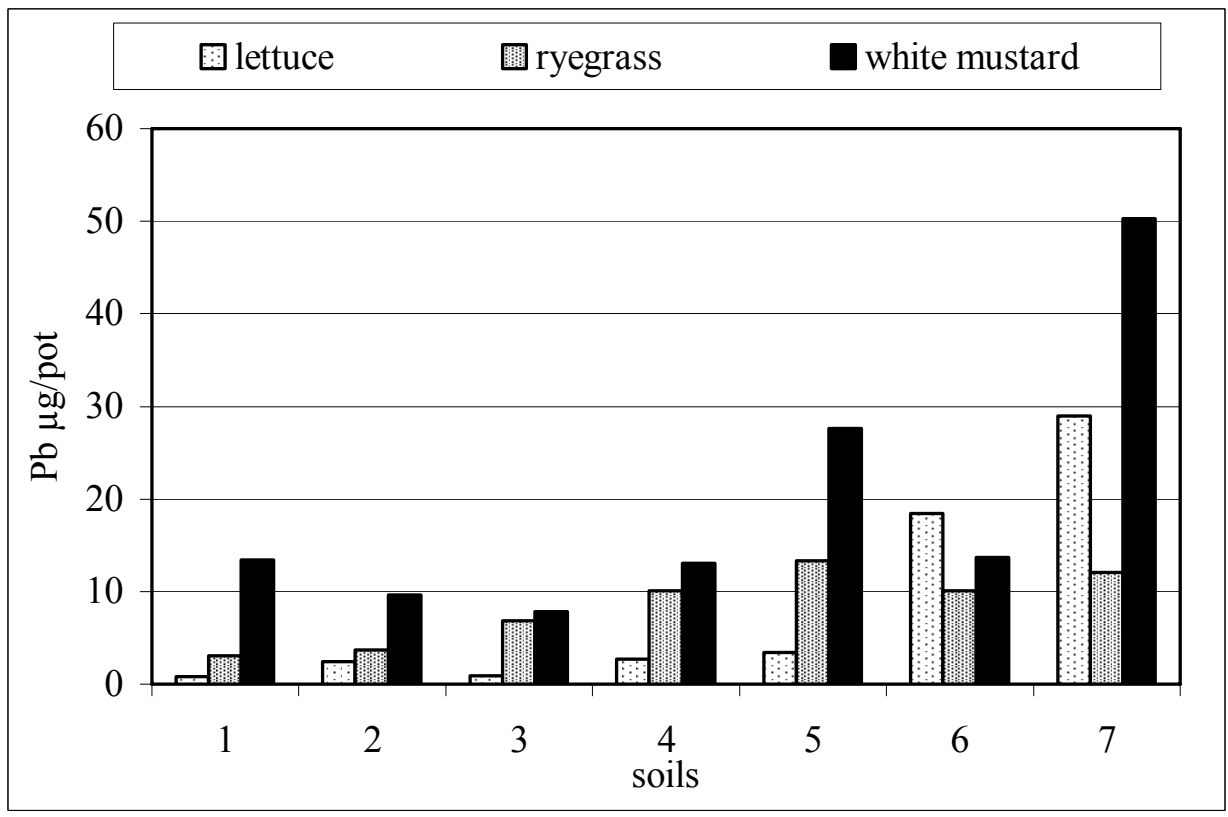

Figure 5

The $\mathrm{Pb}$ uptake by ryegrass, lettuce and white mustard test plants 
concentration of the above-ground plant parts too: lettuce: $\mathrm{y}=0.1387 \mathrm{x}+$ 1.4838, $\mathrm{r}^{2}=0.9791, \mathrm{n}=28$; white mustard: $\mathrm{y}=0.0157 \mathrm{x}+4.3544, \mathrm{r}^{2}=0.5926$, $\mathrm{n}=28$; ryegrass: $\mathrm{y}=0.005 \mathrm{x}+1.7425, \mathrm{r}^{2}=0.315, \mathrm{n}=28$.

According to the $\mathrm{Pb}$ concentration of plants the following order can be set up: ryegrass $<$ white mustard $<$ lettuce. This order was based only on the results of soils with high $\mathrm{Pb}$ contents. It is interesting to mention that in soils (S1-S5) with lower $\mathrm{Pb}$ contents $\left(16-68 \mathrm{mg} \cdot \mathrm{kg}^{-1}\right.$ soil) another order was observed: ryegrass $<$ lettuce $<$ white mustard.

Among the test plants ryegrass showed the lowest $\mathrm{Pb}$ concentration (1-3.7 $\mathrm{mg} \cdot \mathrm{kg}^{-1}$ dry matter), with a more than 3.5 -fold difference between the lowest and highest values.

On soils with lower $\mathrm{Pb}$ content $(\mathrm{S} 1-\mathrm{S} 5)$ the $\mathrm{Pb}$ concentration of white mustard was higher than that of the two other plants (Figure 4). In comparison to ryegrass and lettuce, the $\mathrm{Pb}$ concentration of white mustard was 3-4 and 3-5 times higher, respectively (Figure 3).

The $\mathrm{Pb}$ content of lettuce varied in the widest range $\left(1.3-55 \mathrm{mg} \cdot \mathrm{kg}^{-1}\right.$ dry matter). Outstandingly high $\mathrm{Pb}$ concentrations were measured in lettuce grown on the S6 and S7 soils. In case of the S7 soil the phytotoxicity of Pb could be observed, biomass production decreased significantly. On these soils the $\mathrm{Pb}$ concentration of lettuce - in comparison to ryegrass and mustard - was 1.5- and 5-fold, respectively.

These results are reflected in the quantity of $\mathrm{Pb}$ uptake as well, in which naturally the biomass production was determinant too (Figure 5). The total $\mathrm{Pb}$ uptake by plants showed significant differences due to plants and soils, which originated from the specific uptake characteristics described above and partly from biomass production. The increase of the "total" and $\mathrm{KCl}+\mathrm{EDTA}$ soluble $\mathrm{Pb}$ content of the soil resulted in an increased $\mathrm{Pb}$ content in the test plants, with the values of 0.9 and $50.3 \mu \mathrm{g} \cdot \operatorname{pot}^{-1}$, respectively (Figure 5).

\section{Summary}

The pot experiment - carried out in 2000 under greenhouse conditions - was set up with seven soils differing in $\mathrm{Cd}$ and $\mathrm{Pb}$ contents and three test plants (Lolium perenne L. cv. Georgikon), lettuce (Lactuca sativa L. cv. Balatonzöld) and white mustard (Sinapis alba L. cv. Sirola) with four replicates. From the seven experimental soils five samples (S1-S5) were collected from agricultural areas (arable sites) and two (S6-S7) from spoil-earth, with extremely high Cd and $\mathrm{Pb}$ contents.

The pots, each containing $1 \mathrm{~kg}$ air-dry soil, were kept at constant soil moisture $(60 \%$ of maximum water capacity of the experimental soils) by daily watering, while pots were watered to weight once weekly. Before sowing the 
test plants: $50-50-50 \mathrm{mg} \mathrm{N}, \mathrm{P}_{2} \mathrm{O}_{5}$ and $\mathrm{K}_{2} \mathrm{O}$ was applied to the experimental soils to maintain the same nutrient supply. The above-soil plant parts were cut after four weeks. Fresh and dry weights of plants were determined after harvest.

The aim of the experiment was to obtain results of $\mathrm{Cd}$ and $\mathrm{Pb}$ uptake by different plant species in relation to the heavy metal content and different characteristics of soils. The following conclusions were drawn:

No definite correlation was found between the biomass production of the three test plants and the heavy metal content of the soils at early growth stage. The heavy metal concentration range in the soils and plants differed. In the case of $\mathrm{Pb}$ the soil concentration interval was broader than that of the plants'. The opposite was observed for $\mathrm{Cd}$, where the plants had a wider concentration interval.

Comparing the $\mathrm{Pb}$ and $\mathrm{Cd}$ concentrations of above-ground plant parts, $\mathrm{Pb}$ concentrations varied in a narrower interval. The maximum values of $\mathrm{Pb}$ content exceeded the $\mathrm{Cd}$ content levels, although the mobility of $\mathrm{Pb}$ in the soilplant system is significantly lower. The comparison of $\mathrm{Cd}$ and $\mathrm{Pb}$ concentrations of plants and soils proved these differences. The $\mathrm{Cd}$ concentration of plants was $8-231 \%$ of the total $\mathrm{Cd}$ content of soils.

The $\mathrm{Pb}$ concentration of plants was the $0.8-28 \%$ of the total $\mathrm{Pb}$ content of the soils, respectively. Comparing the three plants in respect of $\mathrm{Cd}$ concentrations the order found was as follows: ryegrass $<$ white mustard $<$ lettuce. In case of $\mathrm{Pb}$, the order depended on the $\mathrm{Pb}$ content level (lower or higher) of the experimental soil. Symptoms of phytotoxicity were observed only on lettuce plants grown on the contaminated soils (S6, S7).

Key words: $\mathrm{Cd}$ and $\mathrm{Pb}$ uptake, lettuce, white mustard, ryegrass

The first author's work was supported by the Bolyai Research Fellowship of the Hungarian Academy of Sciences.

\section{References}

Alloway, B. J., 1995. Heavy Metals in Soils. $2^{\text {nd }}$ ed. Blackie Academic and Professional. London-Glasgow-Weinheim-New York-Tokyo-Melbourne-Madras.

ANDERSSON, A., 1977. The distribution of heavy metal in soils and soil materials as influenced by the ionic radius. Swed. J. Agric. Res. 7. 79-83.

Baranyai, F., FEKETE, A. \& KovÁCS, I., 1987. Results of the Hungarian Soil Nutrient Content Studies. (In Hungarian) Mezőgazdasági Kiadó. Budapest.

BergmanN, W., 1992. Nutritional Disorders of Plants. Gustav Fischer Verlag. Jena 
Chaminade, R., 1960. Experimentation en petits vases de vegetation types d'essais pour tester l'efficacite des engrais humiques. Annales Agronomiques. II. 121-131.

ChAminADE, R., 1964. Diagnostic des carances minerales du sol par L'experimentation en petites vases de vegetation. Science du Sol. II. 157-167.

Davis, R. D. \& CAlton-Smith, C., 1980. Crop as Indicators of the Significance of Contamination of Soil by Heavy Metals. Technical Report No. 140. Water Research Center. Stevenage, UK.

KÁDÁR, I., 1995. Contamination of the Soil-Plant-Animal-Human Food Chain with Chemical Elements in Hungary. (In Hungarian) Ministry of Environment Protection and Rural Development and RISSAC. Budapest.

LehoczKy, É., SzABADOS, I. \& MARTH, P., 1996. Cd content of plants as affected by soil Cd concentration. Commun. Soil Sci. Plant Anal. 27. 1765-1777.

LEHOCZKY, É. et al., 1998. Effect of different soil pH on the Cd uptake by plants. Zesz. Probl. Post. Nauk Rol. 456. 409-415.

MÉSzÁRos, Á. et al., 1988. Atmospheric deposition of $\mathrm{Pb}$ and $\mathrm{Cd}$ in Hungary. (In Hungarian) Időjárás. 92. 134-139.

SzABÓ, I. M., 1992. The Biological Basis of Soil Science (In Hungarian) Magyar Mezőgazdasági Kiadó Kft, Budapest.

TAKÁCS, T., BIRÓ B. \& VÖRÖS, I., 2001. Arbuscular mycorrhizal effect on heavy metal uptake of ryegrass (Lolium perenne L.) in pot culture with polluted soils. In: XIV. International Plant Nutrition Colloquium, Hannover. 480-481. 